\title{
Information Systems For Monitoring And Evaluation Of Company's Value
}

\author{
Anna B. Zhdanova, \\ Department of Management \\ National Research Tomsk Polytechnic University \\ Tomsk, Russia \\ zhdanova_ab@mail.ru \\ Timur R. Rahimov, \\ Department of Management \\ National Research Tomsk Polytechnic University \\ Tomsk, Russia \\ timur.rahimov@gmail.com
}

\author{
Kristina A. Bannova, \\ Department of Management \\ National Research Tomsk Polytechnic University \\ Tomsk, Russia \\ bannovaka@yandex.ru \\ Vladimir N. Sosnin
Contek -Soft, ltd.
vold@ contek.ru \\ Kamenskaya Kseniya Yu. \\ Department of Management \\ National Research Tomsk Polytechnic University \\ Tomsk, Russia \\ kamenskaya@sibmail.com
}

\begin{abstract}
The article deals with the use of information systems for assessment of company's value. Multidimensional analytical groups in this system allow to organize accounting in accordance with Russian and international standards in a single information database. Using the rules of International Financial Reporting Standards allows timely adjustments of assets when they are impaired, which is important for the oil and gas industry today.
\end{abstract}

Keywords - management accounting, IFRS, impairment of assets, economic value added, value-based management, VBS, information systems.

\section{INTRODUCTION}

The financial crisis in the oil market significantly devalued oil and gas companies. "Margin of safety" as the difference between the market price of oil and the cost of its production, which had previously exceeded $90 \%$, is still present, yet significantly reduced. Low level of oil prices requires companies to pay careful attention to evaluation of the effectiveness of their units. Development programs oil companies should take into account policy changes, one of which is the focus on value based enterprise strategy.

An important aspect of the oil companies' management is the use of financial information about the value of the company's business units. Information on the value of the business units requires the use of methodological norms based on international financial reporting standards (IFRS), and modern information systems with with a wide range of analytical possibilities.

The development of modern information technologies has led to the creation of Russian software products that allow parallel accounting according to RAS and IFRS. They also allow to use financial data for expressevaluation of the company's value, which, in its turn, is necessary for managers in order to make effective current and strategic decisions about the company.

\section{MODERN FEATURES OF VALUE BASED MANAGEMENT OF THE COMPANY.}

Enterprise value is an objective indicator of its performance, determining the prospects of its further development. An innovative view of the company's value based management concept is based on two two main approaches: 1) evaluation of added cash flow generated by the company compared with the one invested by shareholders and 2) evaluation of value added, based on the adjusted accounting profit. Several researchers have shown the feasibility of IFRS application to assess the company's value and to improve the functioning of capital markets in general $[1,2,6]$.

To assess the value of the company it is important to focus on strategic investments which enable the company to produce cash flow in the future. These strategic investments in oil companies are investments in deposits, the valuation of which mainly determines the value of the company as a whole. The sensitivity of the investment cash flow to changes in prices of raw materials in the global decline in oil prices was shown for the oil and gas industry companies, such as Niclas Andren, Hakan Jankensgard (2015) [3].

Value management of companies is based on modeling the relationship between the market value of the of companies and its determining factors. Planning and control of the factors determining the change in the value of the company, allows purposefully to form the company's value and in a timely manner to correct the adverse environmental effects.

Modeling the relationship between the market value of the company and cash flow, taking into account a number of factors, including the book value of assets, income components, calculated on an accrual basis, is discussed by Saeed Akbar (2011) [5]. Modelling of the company's value 
can be carried out while using the tool of target costing. That is especially true for oil business in the modern world.

In this approach, the calculation of the target level of costs of the company's business units is determined by the market price of oil and the specified level NOPAT (net operation profit after tax), which provide positive EVA (economic value added). The use of EVA to assess the effectiveness of target costing in managing the material resources of the enterprise is shown by Margaret Woods (2012) [7].

A number of studies show the use of EVA factor models for inventory management and supply chains [8], as well as justify the greater applicability of EVA compared to other financial models for the management of structural subdivisions of enterprises and for the assessment of investment and financial assets $[9,11]$.

\section{THE METHODOLOGICAL FRAMEWORK USED FOR ASSESSMENT OF THE VALUE OF COMPANY'S ASSETS.}

A feature of the oil and gas industry is a significant volume of required capital expenditures. Substantial investment in plant and equipment require measurement at fair value of assets, which in the financial crisis entails the necessity of recording of assets impairment losses. The basis for reflection of losses from impairment of assets is the international standard IAS 36 (Impairment of Assets). Oil and gas assets when there is evidence of a possible reduction in their value are tested for impairment according to the rules of the standard (IAS 36.9).

CGU (cash-generating unit) - is the smallest identifiable group of assets that generates cash inflows that are not dependent on the cash inflows from other assets or groups (IAS 36.6). It is necessary to distinguish between two types of CGU in relation to the oil and gas industry:

1) Assets for development, production, processing and marketing. These assets are subject to traditional rules of impairment testing (IAS 36), which will be discussed in this article [13]

2) Assets related to exploration and evaluation. Their depreciation is regulated by different standards and requirements - IFRS 6 (Exploration for and Evaluation of Mineral Resources) [12].

Often CGU in the oil and gas industry identify deposits and objects of infrastructure that ensure its activities and owned by exploration and production units of company's division. Investment decisions in regard to the deposit is based on the expected volume of production of all field and not just a single well. All wells are usually depending on the infrastructure of the deposit.

Companies use professional judgment to assess any indications of impairment. If the conclusion of any such indication exists, then it is necessary to perform an impairment test in accordance with IAS 36 "Impairment of Assets". [13] Evidence of impairment of oil and gas sector include the reduction of long-term market for oil and gas prices, the revision of reserves towards a substantial reduction, tightening regulation or changes in the taxation, deterioration of local conditions to such an extent that continued operation becomes unsafe, expropriation of assets. If any sign of impairment is present, management must run a test for impairment at the level of the individual $\mathrm{CGU}$, even if this sign has been noticed at the regional level.

Under these conditions, there is a need for information systems, which under given initial parameters would be able to quickly and accurately carry out tests for impairment, as well as to reflect the real value of assets.

\section{FEATURES OF INFORMATION SYSTEM FOR ASSESSING THE VALUE OF ASSETS}

Modern software allows to conduct parallel accounting in accordance with Russian and international standards at the same time, which not only simplifies and accelerates the evaluation of the company's assets, but also allows to receive data about the company's value and its risks.

Evaluation of the oil business should take into account its extraordinary capital intensity. Accordingly, prompt and fair reflection of the value of fixed assets is important in order to assess the company's value. However, the Russian accounting standards and IFRS have different requirements for the evaluation of fixed assets. For accounting and for presenting of financial information in the context of determination of the value of the business it is important to unite management accounting by centers of financial responsibility and methodological basis of IFRS in a single software product.

In this study the information on the evaluation of the business units of the oil company, obtained by using software (ERP-system) of Russian developers was used. Let us consider the features of the software, which allow to use it to assess the company's value. Accounting for fixed assets at initial cost (purchase price, including nonrecoverable taxes and the costs of bringing the asset to a working condition) under IFRS is carried out in the software configuration in parallel with the accounting according to Russian standards. For this purpose there is a special chart of accounts, which allows to keep records in the context of Russian Accounting Standards (RAS), the rules of tax accounting in accordance with the Tax Code of the Russian Federation (RF Tax Code) and International Financial Reporting Standards IFRS (Table 1).

TABLE I - ANALYTICAL LEVELS OF ACCOUNTS OF FIXED ASSETS ACCORDING TO THE SOFTWARE PRODUCT CONTEKSOFT

\begin{tabular}{|c|c|c|c|c|c|c|c|}
\hline $\mathbf{R}$ & I & $\mathbf{T}$ & $\mathbf{M}$ & Code & Title & Type & Analytics \\
\hline $\mathrm{V}$ & $\mathrm{V}$ & $\mathrm{v}$ & $\mathrm{V}$ & 01 & Fixed Assets (FA) & A & \\
\hline $\mathrm{v}$ & $\mathrm{V}$ & $\mathrm{V}$ & $\mathrm{V}$ & 01-01 & FA in operation & A & 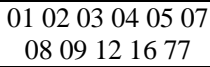 \\
\hline $\mathrm{v}$ & $\mathrm{v}$ & $\mathrm{V}$ & $\mathrm{v}$ & $01-02$ & FA rented out & A & $\begin{array}{c}030405070809 \\
16182577\end{array}$ \\
\hline & $\mathrm{V}$ & & & $01-03$ & $\begin{array}{c}\text { FA taken on a } \\
\text { lease }\end{array}$ & A & $\begin{array}{c}030407121825 \\
99111\end{array}$ \\
\hline $\mathrm{v}$ & $\mathrm{v}$ & $\mathrm{V}$ & $\mathrm{v}$ & 02 & $\begin{array}{c}\text { Amortization of } \\
\text { FA }\end{array}$ & $\Pi$ & \\
\hline $\mathrm{V}$ & $\mathrm{v}$ & $\mathrm{V}$ & $\mathrm{v}$ & 02-01 & $\begin{array}{l}\text { Depreciation of } \\
\text { FA in operation }\end{array}$ & $\Pi$ & $\begin{array}{c}010203070809 \\
121677\end{array}$ \\
\hline $\mathrm{V}$ & $\mathrm{V}$ & $\mathrm{V}$ & $\mathrm{V}$ & $02-02$ & $\begin{array}{l}\text { Depreciation of } \\
\text { FA rented out }\end{array}$ & $\Pi$ & $\begin{array}{c}030407080916 \\
182577\end{array}$ \\
\hline & $\mathrm{V}$ & & & $02-04$ & $\begin{array}{c}\text { Amortization of } \\
\text { FA taken on a } \\
\text { lease }\end{array}$ & $\Pi$ & $\begin{array}{c}030407121825 \\
99\end{array}$ \\
\hline
\end{tabular}


Legend to Table 1:

$\mathrm{R}$ - Accounting according to RAS

I-Accounting according to IFRS

$\mathrm{T}$ - Accounting for tax purposes (tax accounting)

$\mathrm{M}$ - Managerial accounting.

01-01 - Fixed assets in operation

01-02 - Fixed assets rented out and held in safekeeping

01-03 - Fixed assets taken on a lease

02-01 - Depreciation of fixed assets in operation

02-02 - Depreciation of fixed assets rented out and held in safekeeping

02-03- Depreciation of income-bearing investments in tangible assets

03-01 - Property for rent

03-02 - The property rented out

Designations of analytics levels in Table 1

$01-$ level of accountable person

$02-$ level of production facilities

03 - level of accounting of degree of use of fixed assets

$04-$ level of the purpose of the use of property

05 - level of the method of assets growth and disposal

06 - level of the fact of assets operation before acquisition

07 - level of structure and grouping of fixed assets

08 - level of existing restrictions on the assets use

77 - level of inventory number of fixed assets

Table 1 shows the capabilities of the software to conduct parallel accounting. During the input of accounting source document into the information system, it is indicated for which type of accounting (tax, Russian, international, management) will this business transaction be registered with the given analytics.

Code of analytics allows an unlimited number of analytical groups, which may be reported in the financial statements.

The chart of accounts defines a list of analytical sections for each of the accounts. The implementation of these analytical sections is carried out by the organization directories, which provide necessary analytics for each account.

The requirements are designed on the basis of the tasks which are relevant for oil and gas companies, without being tied to a particular software. Consequently, for some automated systems, they cannot be realized in full.
Analytical accounting system in the software product is designed in such a way so that it allows to link different variation of accounting records not limiting them to a standard set of reports. All this reflects the "multidimensionality" of accounting, when accounting data is generated at the same time according to RAS, IFRS, tax and managerial accounting.

Multidimensionality of analytical groups allows to use the software, not only for financial reporting, but also for management purposes, especially for calculation of indicators characterizing the value of the company. In section 4 there is an example of using the software to reflect the impairment of the CGU under IAS 36.

\section{THE USE OF INFORMATION SYSTEM TO ACCOUNT FOR IMPAIRMENT OF ASSETS}

Most assets lose value over time, which is reflected the mechanism of depreciation. However, there are situations in which the fair value of the asset is different from its residual value. In accordance with IAS 36 "Impairment of Assets" asset, including the fixed assets are considered as impaired when its book value exceeds its recoverable value. The recoverable value can be obtained through use or sale of the asset. If there is reasonable evidence of asset impairment for a certain accounting date, a test for impairment is run, in which the recoverable value of the asset is determined. Depreciation is calculated by the $\mathrm{CGU}$, therefore, in accounting information about CGU should be reflected in a special analytics. This analytics of CGU is needed to summarize the book value of CGU assets and compare it with the recoverable value after the impairment test. In the information system the impairment factors are entered in the service table for a particular CGU (Table 2).

TABLE II IMPLEMENTATION OF THE IMPAIRMENT TEST IN THE INFORMATION SYSTEM.

\begin{tabular}{|c|c|c|c|c|c|c|c|}
\hline $\mathbf{1}$ & $\mathbf{2}$ & $\mathbf{3}$ & $\mathbf{4}$ & $\mathbf{5}$ & $\mathbf{6}$ & $\mathbf{7}$ & $\mathbf{8}$ \\
\hline CGU 1 & 45,00 & 1,50 & 43,50 & 43,0 & $(0,50)$ & Yes & 0,011 \\
\hline CGU 2 & 6,09 & 4,09 & 2,00 & 4,00 & 2,00 & No & \\
\hline CGU 3 & 33,00 & 20,0 & 13,00 & 14,0 & 1,00 & No & \\
\hline CGU 4 & 80,00 & 3,00 & 77,00 & 55,0 & $(22,00)$ & Yes & 0,286 \\
\hline Total & $\mathbf{1 6 4 , 0 9}$ & $\mathbf{2 8 , 5 9}$ & $\mathbf{1 3 5 , 5}$ & $\mathbf{1 1 6 , 0}$ & $\mathbf{( 1 9 , 5 0 )}$ & & \\
\hline
\end{tabular}

Indications of columns in the table 2:

1- $\quad \mathrm{CGU}$

2- Initial cost of fixed assets, million rub.

3- Accumulated depreciation of fixed assets, million rub.

4- Residual value of fixed assets, million rub.

5- Recoverable value, million rub.

6- Difference million rub.

7- Necessity of impairment.

8- Coefficient of impairment.

Impairment of assets is accounted for in the debit of account 91 Other expenses (depreciation of assets) and the credit of accounts 01 CGU. Example of entries in accordance with the data in Table 2 is shown in Table 3 .

TABLE III ACCOUNTING FOR IMPAIRMENT OF ASSETS IN THE INFORMATION SYSTEM

\begin{tabular}{|c|c|c|}
\hline Debit & Credit & Sum, million rub. \\
\hline 91 & 01 CGU 1 & 0,50 \\
\hline 91 & 01 CGU 4 & 22,00 \\
\hline
\end{tabular}


As a result of impairment testing, top management receives operational data on the residual value of the assets of the company, but taking into account their impairment (tab. 4).

TABLE IV CALCULATION OF THE RESIDUAL VALUE OF THE ASSETS, TAKING INTO ACCOUNT THE IMPAIRMENT TEST

\begin{tabular}{|c|c|c|c|c|}
\hline CGU & $\begin{array}{c}\text { Initial cost } \\
\text { of fixed } \\
\text { assets, } \\
\text { million rub. }\end{array}$ & $\begin{array}{c}\text { Accumulated } \\
\text { depreciation, } \\
\text { million rub. }\end{array}$ & $\begin{array}{c}\text { Impairment, } \\
\text { million rub. }\end{array}$ & $\begin{array}{c}\text { Residual } \\
\text { value of } \\
\text { fixed assets, } \\
\text { million rub. }\end{array}$ \\
\hline $\begin{array}{c}\text { CGU } \\
1\end{array}$ & 45,00 & 1,50 & 0,50 & 43,00 \\
\hline $\begin{array}{c}\text { CGU } \\
2\end{array}$ & 6,09 & 4,09 & 0,00 & 2,00 \\
\hline $\begin{array}{c}\text { CGU } \\
3\end{array}$ & 33,00 & 20,00 & 0,00 & 13,00 \\
\hline $\begin{array}{c}\text { CGU } \\
4\end{array}$ & 80,00 & 3,00 & 22,00 & 55,00 \\
\hline Total & 164,09 & 28,59 & & 113,00 \\
\hline
\end{tabular}

Presented calculations show that the devaluation of CGU has an impact on the decrease of the asset value and decrease in net operating income of CGU (NOPAT) for the period under review. Hence, such effects should be taken into account when calculating EVA CGU.

Presented calculations show that the impairment of value of CGU has an impact on the decrease of the asset value and decrease in net operating income (NOPAT) of CGU for the period under review. Hence, such effects should be taken into account when calculating EVA of the CGU.

The use of models based on the technology of target costing allows to move from the impairment of assets of CGU to calculation of planned target cost of production through specified level of NOPAT, taking into account the positive EVA condition and the required return on invested capital. Obtained data on target cost of production help to analyze the possible tools to achieve it in the planning period.

\section{CONCLUSION}

It is impossible to ignore the fact that the value of an oil company is influenced to a great extent by a reliable estimate of the value of its assets (including environmental facilities). The Russian practice of accounting, based on the historical value of the assets does not provide prompt and reliable information about their value at any given time. Moreover, if revaluation of assets is not established in the accounting policy of the company, it is not possible to reflect the real value of fixed assets. This doesn't promote transparency, accountability and value for users as well as limits the effectiveness in management and investment decisions. Therefore, orientation of international standards on the current (replacement) value is more appropriate and informative for management reporting and decision-making. Impairment tests allow to reflect the market value of assets in the financial statements for the purpose of management accounting.

\section{REFERENCES}

[1] Evgeny Lyandres, " Costly external financing, investment timing, and investment-cash flow sensitivity", Journal of Corporate Finance, vol.13, 2007, pp. 959-980;
[2] Thomas Schleicher, Ahmed Tahoun, Martin Walker, "IFRS adoption in Europe and investment-cash flow sensitivity: Outsider versus insider economies", The International Journal of Accounting, vol.45, 2010,pp. 143-168;

[3] Niclas Andren, Hakan Jankensgard "Wall of cash: The investmentcash flow sensitivity when capital becomes abundant", Journal of Banking \& Finance, vol. 50, 2015, pp. 204-213.

[4] Mozart B.C.Menezes, Seokjin Kim, Rongbing Huang, “ Return-oninvestment (ROI) criteria for network design", European Journal of Operational Research, vol.245, 2015, pp. 100-108.

[5] Saeed Akbar, Syed Zulfiqar Ali Shah, Andrew W. Stark, "The value relevance of cash flows, current accruals, and non-current accruals inthe UK", International Review of Financial Analysis, vol. 20, 2011, pp. 311-319.

[6] Mahmoud Ezzamel, Hugh Willmott, Frank Worthington, "Shareholder value: The role of accounting in organizational transformation", Accounting, Organizations and Society, vol.33, 2008, pp. 107-140.

[7] Margaret Woods, Lynda Taylor, Gloria Cheng Ge Fang , "Electronics: A case study of economic added", Management accounting Research, vol. 23, 2012, pp. 261-277.

[8] Ashayeri. J, Lemmes L., "Economic value added of supply chain demand planning: A system dynamics simulation", Robotics and Computer-Integrated Manufacturing , vol.22, 2006,pp. 550-556.

[9] Viera Berzakova, Viera Bartosova, Eva Kicova, "Modification of EVA in Value Based Management", Procedia Economics and Finance, vol. 26, 2015, pp. 317-324.

[10] Rastislav Rajnoha, Andrea Sujova, Jan Dobrovic , “ Management and economics of business processes added value", Procedia - Social and Behavioral Sciences, vol.62, 2012, pp. 1292-1296.

[11] Salaga Jakub, Bartosova Viera, Kicova Eva, "Economic Value Added as a measurement tool of financial performance". Procedia Economics and Finance, vol. 26, 2015 , pp. $484-489$.

[12] IFRS 6 - Exploration for and Evaluation of Mineral Resources

[13] IAS 36 - Impairment of Assets

[14] K.A.Bannova, I.N.Dolgih, A.B.Zhdanova, N.V. Pokrovskaya, "Developing The Competitive Advantage Of Companies And Regions By The Creation Of Consolidated Groups Of Taxpayers", IBIMA, 2015, pp. 834-841. 